\title{
Gambier : Indonesia Leading Commodities in The Past
}

\author{
Hamda Fauza \\ Department of Agronomy, Faculty of Agriculture Andalas University, Padang 25163, Indonesia \\ E-mail: hamdafauza@yahoo.com
}

\begin{abstract}
Gambier is one of Indonesia's small holder plantation commodities with a high economic value and has a commercial prospective for the future regard to the various usefulness. Gambier terms, in addition, to use as the name of the plant, is also the trade name of the product produced by the plant, extract of the leaves and young branches of the gambier plant. In Indonesia, gambier have been subsisted in a golden era and be the prominent commodity. In the early 19th century, gambier has become one of the commodities traded in Europe. After World War II, gambier is no longer an important export products that are traded in the international market. Further, development of gambier plantations in Indonesia are not so obvious information. At this time in Indonesia, West Sumatra is the center of gambier production, moreover gambier also called as a specific plants of West Sumatra. Mostly, gambier is produced by small home industries with the traditional tools and use more human labor. Gambier is cultivated and processed in a unique method, therefore, gambier plant development become complicated. However, gambier development in Indonesia especially in West Sumatera for the future is still promising, considering its various usefulness and the role of Indonesia as the world's major producer. Along with to the all contributing factors, there are numerous challenges and obstacles in the development for various aspects of this commodity. Furthermore, intense participation from the stakeholders; government, farmers, researchers, investors, and traders in management ranging from farming techniques, processing, trade, and institutions are necessary. Thus, it could be expected, gambier would be turn around as a foremost commodity in the future.
\end{abstract}

Keywords - gambier, uncaria, cathecine, West Sumatra

\section{INTRODUCTION}

Gambier, heard these words, we will create an object contained in the betel and areca nut with carano ornamental copper bowl), used in custom traditional events on the Ranah Minang, such as: a wedding, inauguration of chieftain, and other customary procession. The usefulness of gambier's famous to date is as a mixer fed of betel, gambier which give a slightly bitter taste or chelate which gradually turns into sweetish. The Minang people call this plant with gambier. De Clercq [8] in his book Meuw Plantkundig woordenboek voor Nederlansch Ind states that in the policy at that time there was an expression of indak tau di gambie (don't know the gambier). This expression is meant to someone who less knowledgeable or someone who does not know good manners. In the phrase the gambier became parameters intelligence, knowledge, and civility.

The term of gambier, beside used as the name of a plant, also a trade name of a product produced by those plants, derived from extract leaves and twigs plant gambir with hot water sedimentated, printed, and dried.

The gambier commodities almost entirely developed in the form of smallholder plantations. Gambier plantation business different and more specific as compared to other estates, as commodities in a series of cultivation activities there are also industrial activities. There is no or rarely selling farmer gambier leaves or parts of its vegetation, but they are sold in the form of dried sap (extract). The production process still is traditional and more use of human power and it is a skill passed down through generations.

Since before World War I, gambier is already became traditional commodities who laboured in Indonesia. Producing areas of gambier still productive only on West Sumatra and became one of the plantation commodities important [7].

At the moment, in the Indonesia gambier largely spread in West Sumatra, gambier so called also as specif plant from this region. Here, more than $90 \%$ of the land in the county there are Limapuluh Kota and Pesisir Selatan District.

Gambier is one commodity that is worth people's economic plantation high. In the future, this prospective commodity grown commercially, considering it a good variety of mixer as traditionally eat the leaves as well as raw materials and auxiliary industries like the pharmaceutical industry, tanners, beverages, paints, etc. The prospect of the development of gambier in the scale of broad and oriented agribusiness, and agro-industry is still has a chance. 
If we looked at a moment backward, it turns out that gambier has ever had an era of triumph and becomes the prima commodities in the past.

\section{GAMBIER PLANT}

\section{A. Origin, Botany, and Ecology}

Gambier (Uncaria gambir (Hunter) Roxb.) is a plant in the family shrub from Rubiceae. Rubiceae family consists of 34 genus, of which one genus found in Africa, in America, the two genus and more over in areas of tropical Asia which is mostly found in the islands of Indonesia [29]. However Uncaria gambir is the best sap gambier producers to trade.

The origin of gambier plants is known with certainty, but allegedly from Southeast Asia, because in that area gambier has been cultivated [12]. These plants most within the Borneo and Sumatra [2]. Heyne [17]; Ridsdale [23] reported that gambier many plants found in Asia, especially in Indonesia and Peninsula Malacca. Regional their spread in Indonesia among others are Aceh, North Sumatra, Riau, West Sumatra, Bangka, Belitung, and West Borneo. Sastrapradja, et al. [27] declaring that plgambier found growing wild in the forests of Sumatra, Borneo, and The Malay Peninsula. In addition it is also grown in Java, Bali, and Maluku.

The shape of gambier plants morphology, including the types of plants and shrubs, when left to grow coiled. Plant height of $1.5 \mathrm{~m}$ to $2 \mathrm{~m}$, the of branch colour is light brown to dark brown, branching many angles of $30^{\circ}-50^{\circ}$ from the main trunk. Oblagus-shaped leaves-ovalis, young green colour, green, brown, and green, with a length of petiole of 0.2 to $0.4 \mathrm{~cm} \mathrm{[5].}$

An research result of Fauza [14] indicating that the area of the environment has gambier plantations variations of being diverse. Based on studies in several locations in West Sumatra, gambier is located at elevation of $100 \mathrm{~m}$ above sea level (asl) in Siguntur up to $850 \mathrm{~m}$ asl in Halaban. Such elevation variation shows that gambier plant could be developed in the lowlands, the medium land, and the upland. Formenly, Tijdschr (1912) cit. Heyne [17]; [29]; [5] have argued that the gambier plants growing well until an altitude of $900 \mathrm{~m}$ asl.

Gambier plants can be reproduced in a vegetative and generative, but propagation of vegetatively hasn't worked well. Cutting had a success rate of about $50 \%$, while the success rate can reach layering $80 \%$ but have difficulty in separation with the parent plant. On the technique of tissue culture has yet to get optimal results but is already showing signs of success and still continue to do research into it. Usually farmers using seeds from the generative reproduction. Seedling is usually done on a somewhat sheltered place [16].

\section{B. Contents of Beneficial Substances and Usefulness}

Gambier extract contains several components, namely cetechin (1-33\%), acid catechu tannat (20-55), pyrocatechol (20-30\%), gambier fluorescence (1-3\%), red catechu (3-5\%), quersetin $(2-4 \%)$, fixed oil (1-2\%), candles (1-2\%), and a little alkaloids [22]. Catechine are not easily soluble in cold water and when the water is evaporated then this is tannat catechu acid crystals that are colored reddish-brown [6].
Traditionally gambier was used as a complement to eat leaves and drugs. In Malaysia the Gambier drug usually used for burns. Gambier Borneo used as headache and lumbago. In Johor, the young leaves and bud decoction is used as remedy for diarrhea and dysentery, as well as a mouthwashgargle in sore throats. Gambier may also be used for disease canker sores, sore skin, diarrhoea, and others [4].

Heyne [17] stated that it was also used in the tanners or fish nets, tanner base material dyeing/colour (especially for dyed silk and military equipment). In addition gambier is also used in breweries to clear beer and as an ingredient in the pharmaceutical industry. Gambier turns can also be utilized as a plant-based pesticides. According to Adria and Idris [1] gambier extract can be used as an insecticide plant. Idris and Adria [18] also reported that gambeir flour is a fungicide. In addition various other benefits of gambier is still in research such as: glues of plywood and particle board [19], gambier pure suction tablets [15], gambier shampoos [28], and others.

\section{Cultivation}

Although it is one of export commodities, the gambier plant cultivation techniques are still done traditionally. In general the activities of gambier cultivation consists of: land clearing and land processing, provision of seed/seedlings, planting, maintenance, and harvesting

Farmers in the cultivation of gambier rely more on fertility of land without fertilizing, so do the productive age 5-6 years, because the plant was not fertile. When reared intensively, age production can reach 20-30 years even more. The land clearing is generally carried out by slash burns at the beginning of the dry season, then the land cleared and burned, then made the planting holes.

Reproduction through seedling is a method that many farmers due to their ease in implementation. Reproduction in the form of seed material is generally provided by farmers by creating a seedling for themselves. Not yet known in cultivation of gambier so-called seeds or superior varieties. Farmers just do a selection naturally from his own plantation. Seedling of gambier include unique and different from other plants, where the seedling is done on the slopes or cliffs with almost $90^{\circ}$ facing east and usually on the type of soil with a high clay content. Usually the seed will grow after 15 days.

Traditional farmers make planting by way of planting varies with distance drill $1 \times 2 \mathrm{~m}$ to $3 \mathrm{~m} \times 3$. Planting done by attaching the seeds on the ground away from the pit and pit-no need for closure of the pit. Whereas for seedlings grown in polybags, created an aperture with a size of 10-15 $\mathrm{cm}$ in width and depth of $30-40 \mathrm{~cm}$.

Regular maintenance performed on the cultivation of gambier only control weeds. Weed control is conducted two to three times a year in accordance with the period of harvest. Fertilization with artificial fertilizers are very rarely even have never done. Fertilization only with organic fertilizer by-product use kempaan (processing) of which there are quite a lot. Delivery is carried out by means of spreading the 'kempaan' fibres around the plant.

Harvesting can be done already at the age of one and a half years. First harvest by cutting branches following leaf with a long piece of 40-60 $\mathrm{cm}$ from the ends of the twigs. Furthermore this is as the end product of the process of 
cultivation. Gambier plant cultivation activities grooves can be seen in Figure 1.
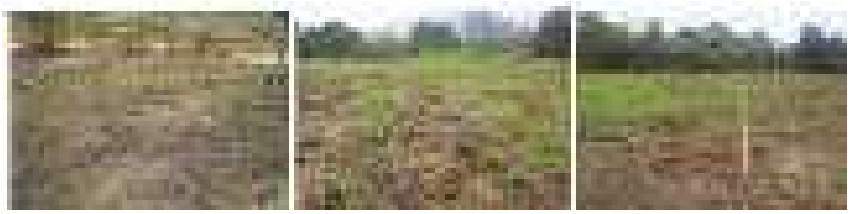

Land clearing and land processing
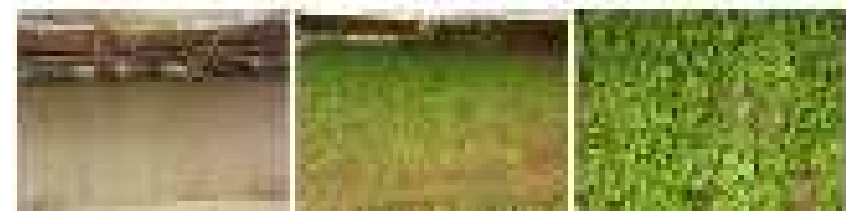

Seedling
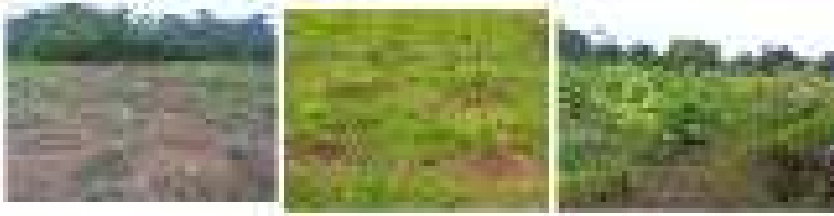

The plants age 3 months (left), 6 months (center), and 9 months (right)
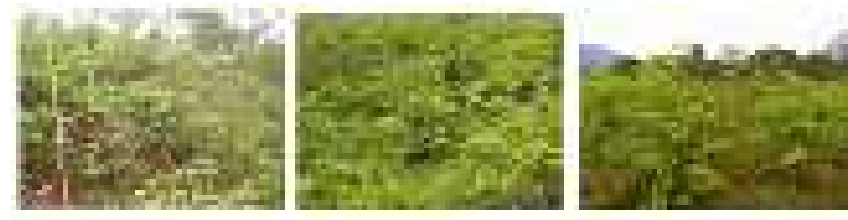

Gambier plant is ready to harvest

Fig. 1 Gambier plant cultivation activities grooves

\section{Processing}

Processing generally consist of six stages, namely: packing, boiling, pressing, deposition, forming, drying out.
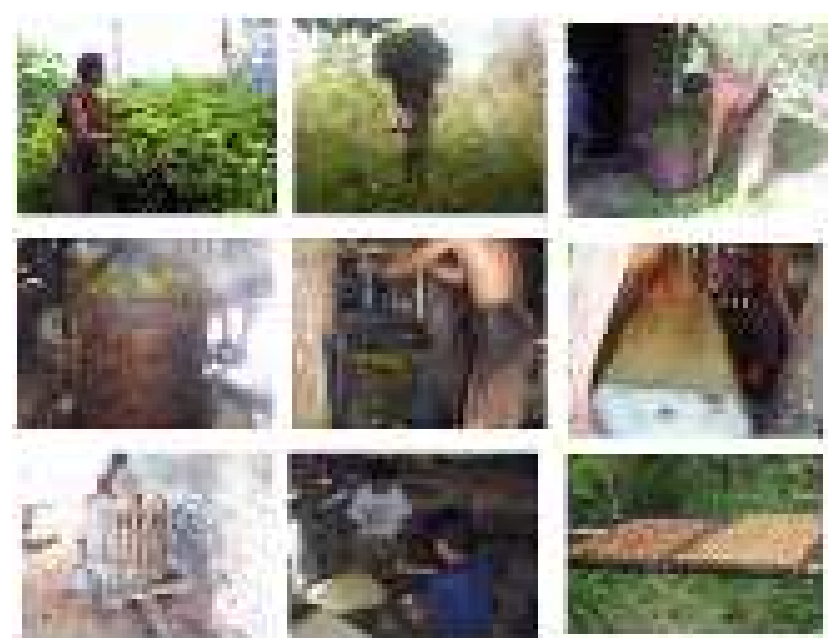

Fig. 2 Porocessing gambier exctract

Packing is to enter and condense yields (young leaves and twigs) into a container of bamboo. Then boiled for an hour with a high temperature. Results of the stew using traditional spring pressed, so sap and other content out liquids. The liquid is deposited during a single night, so it will be separate from the water with sap and other content. Then the water is discharged and as shaped like the last batter printed and sun-dried. For more details can be seen in Figure 2.

\section{DEVELOPMENT OF THE COMMODITIES BUSINESS OF GAMBIER}

\section{A. Before World War II}

In Indonesia, gambir laboured long ago in the form of people's estates and private estates. Zejlstra [29] states that at the beginning of the $19^{\text {th }}$ century had become one of gambier commodities in trade in Europe. In 1892 recorded some private estates have been aiming at a company plant Gambier with locations in North Sumatra, West Sumatra and Riau. In general gambier laboured on in almost all areas outside Java, especially in the Riau Islands, the West and the East coast of Sumatra, Bangka and Belitung, Indragiri, and West Borneo.

Gambier plant concession has been done professionally and use advanced technology to measure time. Gambier, processing is using the most modern technical equipment according to the principle of diffusion that produce to gambier bullion is exported to Europe. In Tanjung Pati, West Sumatra, there are gambier research farm who performs various functions research to be recommended on publiclylisted plantation company that exist. In this period, also recorded a lot of publication on plant gambir, ranging from cultivation until on the processing and its trading. Until 1925 statistics gambier trade recorded well. As data at export of various port and distribution domestic trade still listed well. In the period 1920-1940 total production of Indonesian gambier reached 15.000 tons a year, a mostly exported to England and United States, and in small quantities to Germany, Dutch, and Singapore. The price of gambier at that time at between us $\$ 100-400$ per ton [29].

\section{B. The Aftermath Of World War II}

After World War II, gambier is no longer an important export product is traded in the international market. Europe and the United States are looking for sources of catechine and tannins (contained in gambir extract) from another plant or synthetic as a replacement. Further development of gambier in Indonesia is not so obvious information. Some opinions say that the business of gambier compete compared to other commodities such as palm oil, rubber, tea, cinnamon, and so the land that formerly constituted the area of gambier plant replaced. There are also allegations that it was the outbreak of World War II, in which the world trade be disrupted so that Europe is no longer importing gambier from Indonesia. This causes the existing plantations of gambier became bankrupt [29].

Fauza [14] reported that the business is surviving gambier plantations on some people's gambier sentry in West Sumatra to meet domestic needs. Here's what later evolved over time until now, so the specific commodity called gambier West Sumatra. Here's what later evolved over time so that by the end of the 1970s, Indonesia started returning as gambier exporter. 


\section{Present}

At the moment, in Indonesia, West Sumatra is commodity production center gambier and also known as even plants specific West Sumatra. In West Sumatra, this plant does not spread on the whole territory, but concentrated in Limapuluh Kota and Pesisir Selatan. Gambier plant which is in Pesisir Selatan also comes from Limapuluh Kota, brought on by tobacco merchants who came from the base, at the beginning of the $20^{\text {th }}$ century. The last time some of gambier is also developed in some areas, such as: Tanah Datar, Sawahlunto, West Pasaman, Pariaman, and Solok.

On 2008 the total area tercacat area of gambir plant 19.663 ha Sumatra increased to 21.412 ha in 2011 with despite an increase in per year fluctuates. Whereas the production, in the same period has increased which means, i.e. from $13.897 \mathrm{t}$ in 2005 into $13.930 \mathrm{t}$ in 2011 [11]. Meanwhile, the export volume in 2005 Indonesia recorded gambir $7.202 \mathrm{t}$ with a value of US \$ 13.478 thousand, increased to $18.297 \mathrm{t}$ with a value of US \$ 38.038 in 2009 with nearly fluctuates annually. Indonesia recorded as the world's major producers of gambier. Most of the production is exported to Indonesia gambier destination country export among others are India, Pakistan, Taiwan, and Singapore [3]. The export price of gambir per $\mathrm{t}$ is approximately US $\$ 3,200$ [21], while the prices at farmers ' level of Rp 18.000 - Rp 27.000 per kg. Comparison of gambier concession former and now can be seen in Figure 3.

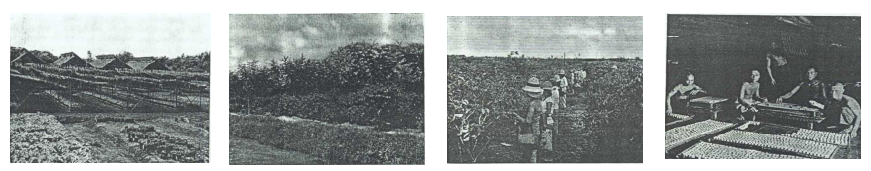

The estate of gambier on the concessions of the Gunung Madoe (photo: Dr. Schneider is quoted from Zeijlstra (1949))

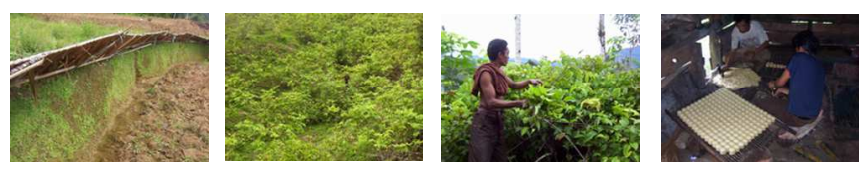

Gambier concession on a smallholder plantation in West Sumatra (photo: Fauza (2007))

Fig. 3 Comparison of gambier concession former and now

\section{THE OPPORTUNITIES AND CHALLENGES OF DEVELOPMENT}

\section{A. The prospects and opportunities}

Indonesia is the only country exporting gambier in the world, still in the form of raw. If indonesia able to process gambier into form other products of added value will increase Indonesia gable to process gambir into fo gambier farmers. Meanwhile, the importing countries are already getting a huge added value by performing the process or other benefits [22].

Gambier plant development prospects in a wide scale and oriented towards agribusiness and agro-industries is still very had a chance. Some factors that support this according to the Nazir [22], including: (1) Indonesia is the world's only exporter of gambier, (2) Indonesia gambier farmers have had a lot of experience in pursuit of gambier, (3) return on investment business not so long time, as gambier can already harvested at the age of one and a half years, (4) plant tolerant of marginal land and the slopes, (5) product damaged though not quick gambier is kept somewhat longerand (6) of this plant can be harvested in a sustainable way. Idris and Adria [18] stated that some aspects that support the development of gambier plant among others are: (1) demand for gambier always increases, (2) the tendency of society to wear natural material in industrial products, (3) maintain the existence of these commodities as a source of foreign exchange particularly West Sumatra, and (4) there are still farmers in the production center's loyal and rely their life at gambier plant. In terms of financing, industrial estates and business is not a business in need of gambier capital. Venture capital is needed in this effort for the vast area of 1 ha and one processing unit is approximately IDR 25 million. Generally, gambier can already harvested at the age of 1.5 years. When the harvest is done twice a year with the production of 1 tons per harvest and assuming an average price of IDR 22,000 gambier per $\mathrm{kg}$, then after deducting the cost of processing the results, venture capital can reach the break event point (BEP) in third.

\section{B. The problems the challenges and solutions}

A side from the prospect and opportunity is promising, in the development of industrial estates and there are also an awful lot of gambier problems and challenges that need solutions. Each stage and the parties involved in the process of development starting from gambier superior varieties. Assembly technique of the cultivation and processing of results, socio-economic and socio-cultural communities, as well as institutional gambier farmers each have problems that cause the results obtained have not contributed optimally for all parties, especially farmers and processors gambier as most parties involved.

In terms of assembly of superior varieties, so far has not produced the material reproduction of superior variety, which can contribute to improving the productivity of gambier. Researches on gambier plant breeding are very far behind compared with other agricultural commodities. Gambier plant breeding is still not much is examined in depth as evidenced by the large number of publications that are not adequate on this subject. So also from the aspect of the cultivation techniques, various research done yet directional and can be applied in the middle of the community. Problems such as fertilization, no fertilizing recommendations that can be made into guidelines for farmers to undertake fertilization on grounds of his plantation. Almost the same thing also happened in other aspects of cultivation, such as weeding, pest and disease control, and others.

Actually, the resulting productivity by farmers is still below the potential results that can be achieved. productivity at the level of farmers ranged from $400 \mathrm{~kg}$ to $600 \mathrm{~kg}$ per ha [25] ; [10]. While, Kusuma et al. [20] states gambier productivity from West Sumatra varies from $65,6 \mathrm{~kg}$ to 432 $\mathrm{kg}$ per ha per harvest. Theoretically, the potential results of this plant can reach 2,100 kg per ha [26].

Low productivity is among other things due to the cultivation techniques are still traditionally has not used quality seeds, fertilizer and maintenance not done adequate, how to plant and harvest, as well as the processing of results has not been effective and efficient [9]; [24]. Increased 
productivity can be performed by intensification and extensification. Extensification of broad through the addition of land area and intensification through improvement of technical culture. One of the efforts in the improvement of technical culture is the use of good reproduction quality.

Then, from the aspect of the processing of the results, it is still done in a simple and use a very simple technology and traditional. This causes yield gambier (extract) acquired has not been optimal. Processing of gambier is not showing the significant development and a touch of technology along with the development of technology from time to time. Procedures for the processing of gambier which is now done, each follows ancestor of what is done in the past. In addition, product diversification also doesn't progress means. In general, gambier which is exported for sale/extract (gum) gambir which is the same as what are the raw materials of the exported centuries ago. The research with regard to product diversification gambier had pretty much produced, such as the manufacture of pure cathecine, gambir utilization for cosmetics and drugs, and others, but has not contributed to the development of this commodity.

Meanwhile, the main problem is that marketing has always been a problem for gambier farmers. There are two fundamental problems in marketing of gambier, the extreme price fluctuations and the obscurity of the trade system. Due to the uncertain gambier prices caused gambier farmers processing do not get certainty in the development. In determining prices, farmers have very low in the bargaining position, not even able to determine at all and tend to accept the price determined by the condition of the buyer (buyers market). Even traders also sometimes collectors also acts as the middleman. Gambier processing farmers did not know how the chain of gambier real commerce.

The reality on the ground shows that gambir processing farmers are still living in a tough economy. Most of them are still subject to a middleman in the management of his business. Even for routine maintenance such as weeding costs they had to borrow to the middleman.

Other problems that become barriers in agricultural and industrial ventures gambir is a matter of social and culture, i.e., the limited ability of the farmer human resource processing. Gambier-producing area in general is an area of the edge of an area bordering a forest and within a fairly far away from the capital of the district is the center of activities, especially education. Such a condition is very influential to the educational level of the community gambier farmer processing. It is clearly visible from the level of community welfare in gambier regions. From a financial standpoint, they have enough income from industrial estates and business gambirnya. However, the use of the financial and management have not been conducted effectively and efficiently and according to properly in accordance with the scale of priorities.

\section{CONCLUSIONS}

Gambier is the specific commodities Indonesia that at the moment more is produced in West Sumatra, economically had developed on prospects for the future. In addition to having prospect and opportunities, in development there are many issues and challenges that need to be resolved the solution. Business development of estates and industrial of gambier will work with tackling the various challenges and obstacles are intact and comprehensive assembly of superior varieties ranging from engineering, cultivation, processing, socio-economic, socio-cultural and institutional based on principles of sustainable agriculture and environmentally, and diversify its products through the involvement of various stakeholders; industrialist seedling (variety), farmers, traders, investors, researchers, extension officers, and government.

\section{REFERENCES}

[1] Adria dan H. Idris. 1996. Studi pendahuluan penggunaan ekstrak gambir sebagai insektisida nabati terhadap larva kumbang colorado (Epilachna sp). Laporan Penelitian Kelti Hama IPPTP Laing. Solok. 14 hal.

[2] Asia Maya. 2004. Gambir (Uncaria gambir Roxb.). Melalui <http://www.asiamaya.com/> [30/03/04].

[3] Badan Pusat Statistik. 2010. Statistik perdagangan luar negeri. Ekspor. Badan Pusat Statistik. Jakarta.

[4] Bakhtiar, A. 1991. Manfaat gambir. Biro Bina Pengembangan Sarana Perekonomian Daerah Tk. I Sumatera Barat. Padang.

[5] Balai Informasi Pertanian Sumatera Barat. 1995. Pemupukan dan pengolahan gambir. Departemen Pertaian. 40 hal.

[6] Burkill, I.H. 1966. A Dictionary of the Economics Product of the Malay Peninsula. Vol I (A-H). Goverments of Malaysia and Singapore by the Ministry of Agriculture and Co-operatives. Kuala Lumpur. Malaysia.

[7] Daswir dan I. Kusuma. 1993. Sistem usaha tani gambir di Sumatera Barat. Media Komunikasi Penelitian dan Pengembangan Tanaman Industri (11) : 68-74.

[8] De Clercq, F.S.A. 1909. Meuw. Plantkundig woordenboek voor Nederlansch Indie. Druk van J.H. De Bussy. Amsterdam. 395 hal.

[9] Denian, A., dan Suherdi. 1992. Teknologi budidaya dan pascapanen gambir. Temu Tugas Aptek Pertanian Sub Sektor Perkebunan. 5 - 8 Oktober 1992. Bukittinggi

[10] Dinas Perkebunan Sumatera Barat. 1998. Statistik Perkebunan. Dinas Perkebunan Sumatera Barat. Padang.

[11] Dinas Perkebunan Provinsi Sumatera Barat. 2012. Data dan Statistik Perkebunan Sumatera Barat Tahun 2012. Dinas Perkebunan Provinsi Sumatera Barat.

[12] Djarwaningsih, T. 1993. Gambir. Dalam : Sutarno, H., H. Pudjaatmaka, dan S. Danimihardja (Eds.) Pendayagunaan Tanaman Penghasil Bahan Pewarna dan Penyamak pada Lahan Kritis. Yayasan Prosea Bogor. Hal 16-18.

[13] Fauza, H. 2005. Gambir (Uncaria gambir (Hunter) Roxb.). Dalam : Baihaki, A., Hasanuddin, Elfis, P. Hidayat, A. Sugianto, dan Z. Syarif (Eds.) Kondisi Berapa Plasma Nutfah Komoditi Pertanian Penting Dewasa ini. PPS Unpad - KNPN Litbang Deptan. hal 167186.

[14] Fauza, H., Nurainas, I. Ferita, Jamsari, A. Dhalimi, A. Denian, dan Murdaningsih H. K. 2009. Eksplorasi dan Identifikasi Plasma Nutfah Gambir dari Genus Uncaria di Sumatera Barat. Makalah pada Semirata Dekan BKS-PTN Wilayah Barat, Untirta Serang 15 April 2009.

[15] Firmansyah, A. Bakhtiar, dan E. Rahmawati. 2004. Pengaruh konsentrasi metil selulosa dalam formulasi tablet murni. Seminar Nasional Tumbuhan Obat Indonesia XXVI. Padang 7-8 September 2004.

[16] Hasan, Z., A. Denian, Iran, A.J.P. Tamsin, dan B.Burhaman. 2000. Budidaya dan pengolahan Gambir. BPTP. Sukarami. 29 hal.

[17] Heyne, K. 1987. Tumbuh-tumbuhan berguna Indonesia Jilid III (terjemahan Nur Udin). Badan Litbang Kehutanan. Jakarta. Hal. 1767-1775.

[18] Idris, H dan Adria. 1997. Kajian awal penggunaan tepung gambir sebagai fungisida nabati terhadap jamur inperfect (Fusarium sp) penyebab penyakit bercak daun pada tanaman klausena (Clausena anisata). Laporan Penelitian Kelti Hama IPPTP Laing. Solok. (tidak dipublikasikan).

[19] Kasim, A. 2004. Peluang dan tantangan pemanfaatan gambir sebagai bahan baku perekat pada industri kayu lapis dan papan partikel. Seminar Nasional Tumbuhan Obat Indonesia XXVI. Padang 7-8 September 2004.

[20] Kusuma, I., Z. Hasan, dan Daswir. 1994. Beberapa aspek budidaya tanaman gambir. Makalah disampaikan pada Simposium Tanaman 
Industri di Puslitbangtri di Bogor 21-23 Oktober 1994. Prosiding Seminar Litro No.06/1995. Hal 8-17.

[21] MyRMnews. 2009. Wapres Kalla lepas ekspor gambir ke Nepal. Melalui <http://www. myrmnews.com > [14/04/09].

[22] Nazir, N. 2000. Gambir, Budidaya, Pengolahan, dan Prospek Diversifikasinya. Hutanku. Padang. 136 hal.

[23] Ridsdale, C.E., 1992. Uncaria gambir (Hunter) Roxb. In Lemmens, R.H.M.J. \& Wulijarni-Soetjipto, N. (Eds.): Plant Resources of SouthEast Asia. No. 3: Dye and tannin-producing plants. Prosea Foundation, Bogor, Indonesia. pp. 125-127.

[24] Risfaheri, Emmyzar dan H. Muhammad. 1991. Budidaya dan pasca panen gambir. Temu Aptek Pertanian. Solok 3 - 5 September 1991.
[25] Roswita, D. 1990. Prospek tanaman gambir di Sumatera Barat. Bul. BIP Padang (01): 8-10.

[26] Sastrahidayat, I.R. dan Soemarsono, D.S. 1991. Budidaya Tanaman Tropika. Usaha Nasional. Surabaya.

[27] Sastrapradja, S., S. Dinimihardja, R. Soejono, N.W. Soetjipto, M.S. Prana. 1980. Tanaman Industri. PN Balai Pustaka. Jakarta. 132 hal.

[28] Shanie, M., V. Hosiana, A. Bakhtiar. 2004. Formulasi. Shampo gambir murni. Seminar Nasional Tumbuhan Obat Indonesia XXVI. Padang 7-8 September 2004.

[29] Zeijlstra, H.H. 1949. Sirih, pinang, en gambir. In: van Hall, C.J.J., \& van de Koppel (Eds.): De Landbouw in de Indische Archipel (Agriculture in the Indonesia Archipelago). Vol. 2B. van Hoeve, 'sGravenhege, the Netherlands. pp.: 578-61 